TURIZAM

Volume 25, Issue 1

1-10 (2021)

ORIGINAL

SCIENTIFIC PAPER

\title{
Hunting Tourism as a Factor for Economic Development of Hunting Associations on the Territory of the City of Leskovac
}

\author{
Bratislav Pešić ${ }^{A}$ \\ Received: July 2020 | Accepted: August 2020 \\ DOI: 10.5937/turizam25-27492
}

\begin{abstract}
The subject of this study is the impact of hunting tourism on the development of hunting associations in the territory of the City of Leskovac in Serbia. Non-experimental model of scientific research, survey, was applied in the paper, while the obtained results were processed by statistical data processing. Data are presented in tables and graphs. The total number of completed questionnaires by service users was 475. The largest percentage of hunters on hunting grounds were foreign tourists compared to domestic tourists, which accounted for $84.50 \%$ of the total number of hunting tourists in 2017, 87.1\% in 2018 year and $898 \%$ in 2019. The income generated from the stay of hunters' tourists was used by hunting associations for the purchase of certain game species and the modernization of hunting and technical facilities. The amount of revenue generated increased by 2.3\% each year in 2018 and by 22.6\% in 2019. Investments in 2017-2019 were up 20.1\% in 2018 to 38.8\% in 2019, while funds earmarked for wildlife procurement were significantly higher by $3.8 \%$ in 2018, and 50\% in 2019. It can be concluded that hunting and hunting tourism must be focused on habitat conservation, environmental protection, and wildlife protection and a very important segment of the economic development of hunting associations and the entire territory in which hunting associations operate.
\end{abstract}

Keywords: hunting, hunting tourism, hunters, wild animals, hunting facilities.

\section{Introduction}

Hunting played an important role in the survival and development of humanity. In modern society, hunting is no longer a matter of survival and food security, but a recreational sport and hobby, an activity that provides economic, sports and recreational value of man. In a broader sense, many authors believe that hunting is a form of recreation and active stay in nature. Prticipants in hunting adhere to certain rules (Marić, 2003).

A Academy of Southern Serbia, Department of Agricultural and Food Studies, Ćirila i Metodija 1, 1840o Prokuplje, Serbia; Corresponding author: batta.pesic@gmail.com 
Hunting tourism is characterized by certain specifics, but for its success it is necessary to have a certain available fund of one or more species of game. The development of hunting tourism is based not only on the number, but also on the type of hunting game, as well as on the trophy structure (Garača et al., 2019). Hunting associations have a big role in that. Serbia is a country of good hunting grounds, good hunters and good hosts. It owns over 320 hunting grounds on about 6.500.00o hectares, which are located on a land configuration from 70 to 2.0oo meters above sea level. There are 44 commercial hunting grounds in Serbia, and other hunting grounds are managed by hunting societies, which also organize commercial hunting on their fields (LSS 2019). In order for a specific hunting ground to have all the necessary tourist references, it should meet the basic criteria set before a tourist destination in general, which is, by definition, "a more or less complete geographical unit with attractive, communicative and receptive factors, ie. all those natural, social, anthropogenic, cultural-historical, traffic and preconditions for accommodation, food, rest, recreation and entertainment of tourists (ie built tourist offer) " (Marić, 2003). Hunting tourism is one of the very specific forms of economic activity precisely because of the specificity of the supply and demand it provides to service users (Čomić, 1988) and (Law on Tourism, 2009). Hunting tourism is, in fact, a complete tourist product at a given destination (hunting ground) and assumes a synthesized sum of products, services and other tourist values in the function of satisfying hunting tourist demand of potential clients (tourists - hunters), as well as a measure of sustainable development of rural areas (Riznić et al., 2019).

Modern economic processes are increasingly eliminating traditional socio-economic relations and destroying antagonistic relations between developed and underdeveloped countries, and Prentović (2014) in his work. We further state that the dominance of world capital will increase the number of segmental groups, highly paid tourist consumers with the constant application of the rule of principle, "have" over "be", which means a new redistribution of tourist resources. This redistribution requires new investments in the development of tourist destinations, but also a new form of tourist product of the highest quality. Due to that, free time received a new redistribution in such a way that rich countries use it more and more for entertainment and recreation of their people, and poor ones more and more to create additional positional capital to satisfy the needs of the rich, but also to raise their own living standards. Modern trends in economic relations are changing and understanding tourism as a global process (Pivac et al., 2020). This means that tourism goes beyond the framework of "industry" and becomes a socio-economic phenomenon. Its further development, product formation and opening of new destinations are the result of previous experiences and new wishes of tourist consumers. Important economic factors of business and development of hunting tourism are its resources, which, individually, are numerous, but they analyze economic and tourism theories can be divided into four basic groups and up to: natural resources, physical capital, human resources, knowledge and hunting dog (Whitelaw et al., 2014).

The natural resources of hunting tourism are hunting game and its habitats where it exists, where game is the main resource of hunting tourism, because it is directly usable. According to Marić (2003) indirectly, "all natural elements and phenomena, regardless of their economic status (capital or resource) have their place and important role in maintaining the natural balance, ie the food chain. Therefore, those species of wild animals that are not included in hunting have an important role in the sustainability of hunting game, ie hunting resources. Wildlife habitats, which are also a natural resource, are in hunting grounds. Areas of hunting grounds, in relation to whether hunting is allowed on them or not, are divided into hunting and non-hunting areas. In addition, hunting grounds can be open in which unhindered sea- 
sonal migration of game takes place and fenced, which, as their name suggests, are fenced with natural or artificial barriers, and game is prevented from leaving this area.

Material and technical resources of hunting tourism, material and technical facilities, as the physical capital of hunting tourism are intended to provide conditions for the implementation of hunting tourism activities.

Thanks to the realization of profits that are realized from the collection of certain game (and especially hunting trophies), hunting tourism is a kind of tourist economy, where natural resources (game) are directly consumed, which is not the case with most other selective forms of tourism.

Subject of researchis to assess whether the territory of the City of Leskovac and its surroundings have or have not the potential for the implementation of hunting tourism projects, including relevant factors that are part of the hunting area system. Also, this research will be focused on determining the capacity for the organization of hunting tourism that will affect: nature protection, conservation of biodiversity, economic benefits, as well as the sustainable development of rural areas.

\section{Hunting tourism in Serbia}

Hunting tourism in Serbia has a long tradition in a number of regulated hunting grounds, but as a small part of tourism it has not received special attention in the tourist literature (Lazić et al., 2008). Tourism is a trip for the purpose of recreation, pleasure or work and is usually of limited duration. Hunting tourism is a special selective form of tourism and, as such, represents "movement and active stay of tourists - hunters in a specific environment - hunting ground, as part of a healthy natural environment, for hunting (shooting, capturing, observing, photographing and shooting) game, thus satisfying their strong motive (Prentović, 2008). Hunting tourism is one of the most attractive segments of the tourist offer, especially for the foreign market. Until the beginning of the 199os and the break-up of Yugoslavia, it was the most important in the field of tourism and catering, since it was a significant source of foreign exchange income.

Hunting tourism is characterized by certain specifics, but for its success it is necessary to have a certain available fund of one or more species of game. The development of hunting tourism is based not only on the number, but also on the type of hunting game, as well as on the trophy structure (Trišić, 2020).

The current situation was greatly influenced by the war during the 1990s, especially in the countries where the largest conflicts took place (such as Bosnia and Herzegovina) and where wildlife habitats were severely devastated and many wildlife populations were brought to the brink of extinction. Serbia, Slovenia and Croatia have the most developed hunting tourism.

The forerunners of tourist hunting in our country date back to the period between the two world wars, in the form of "guest hunts". The interest and stay of tourist hunters, especially English and Germans in the then Danube Banovina (today's Vojvodina) and the participation of the Association of Danube Banovina Hunters at the First World Hunting Exhibition in Berlin, represents the beginning of hunting tourism in our country. However, the beginnings of organized hunting tourism happened only after World War II, in 1952, when 9 foreign hunters visited the hunting grounds near Apatin and Bezdan. Since 1954, when the World Hunting Exhibition was held in Düsseldorf, hunting tourism in our country began its upward trajectory until 1991. In that period, there were about 10.000 foreign hunters in Serbia, from which a 
foreign exchange inflow of 10 million German marks was realized. If these data are compared with the number of tourist hunters of the former SFRY (25-30.00o) as well as with the realized annual income (according to some estimates 20 million dollars), it is clear that Serbia was the most developed in terms of hunting and tourism in relation to other republics. Since 1991, after the disintegration of the SFRY, with the introduction of sanctions and finally with the aggression on our country, hunting tourism has almost died out. The state of hunting and hunting tourism began to slowly improve at the beginning of this century, but despite the achieved results, hunting tourism in Serbia did not achieve the expected revitalization (Prentović, 2014).

According to Prentović (2005b), tourist hunting in our country dates back to the period between the two world wars and to the formation of "guest hunting". The state of hunting and hunting tourism began to slowly improve at the beginning of this century, and not to compare the achieved results, hunting tourism in Serbia was not achieved with the expected revitalization. Hunting tourism in Vojvodina has a long tradition. Vojvodina was the most developed hunting and tourist area in the former Yugoslavia and one of the leading hunting and tourist destinations in Europe, and it is still in the Republic of Serbia today.

An important segment of every (even hunting tourist) destination are adequate facilities for accommodation (accommodation, food) and services in the hunting ground. These are comfortable hunting houses, ie hunting huts, houses for housing hunting dogs, facilities for sports and recreation, cultural and entertainment activities. This also includes facilities and means

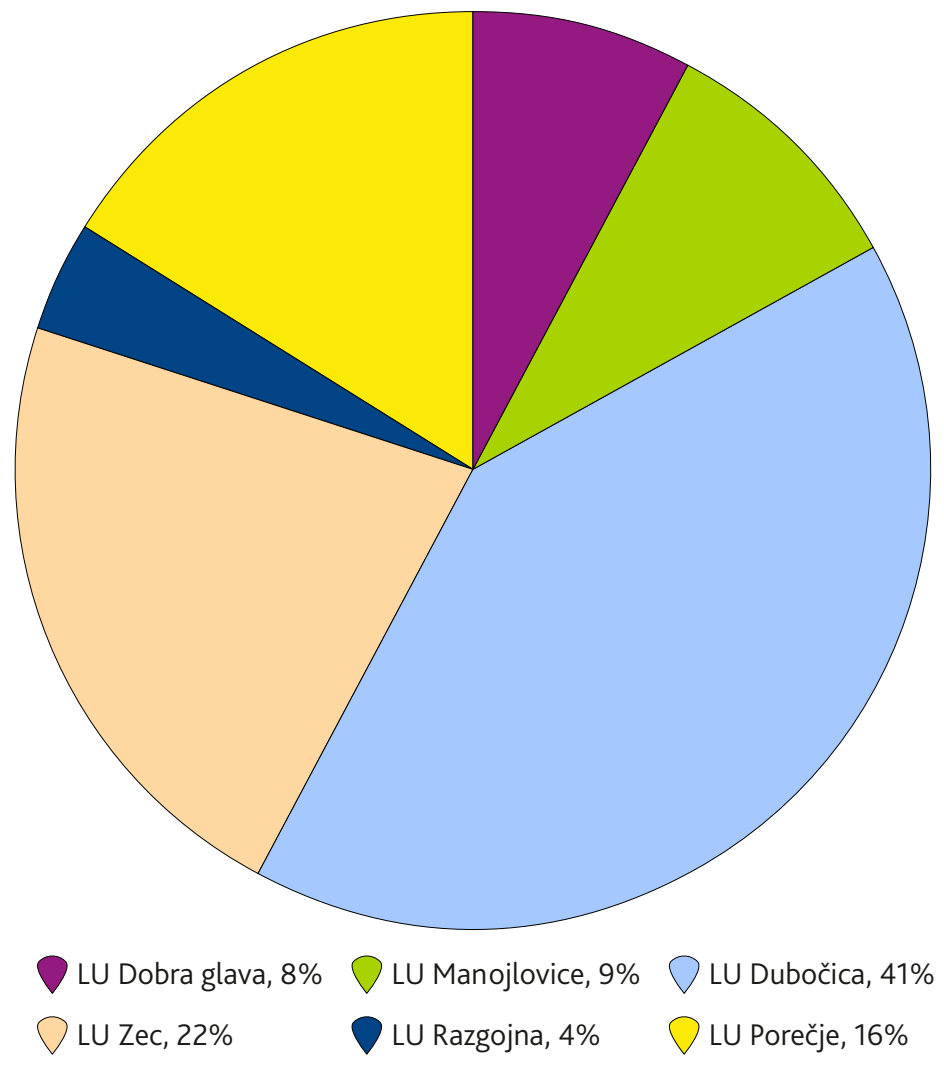

Figure 1. Structure of hunting grounds on the territory of the City of Leskovac

Source: Survey output 
for transporting tourists-hunters from receptive facilities to hunting areas where the program of a given tourist hunt is implemented, and these are appropriate communications within the hunting ground and means of transport such as: off-road vehicles, carriages, sledges, boats, speedboats, etc. vessels, helicopters, etc. The potential for the development of tourism in the city of Leskovac is the mountain Kukavica, which is located between the Vranje valley in the south, Leskovac in the north, or. Grdelica gorges in the east and the valley of Veternica, with the highest peak Vlajna (1441 m). Mount Kukavica has natural conditions for the development of mountain and hunting tourism, given the richness of game, of which the most important are wild boar and roe deer (Pesić et al.,2019; Stolić et al., 2019). Other species of game and birds, as well as the presence of predators, dominate these areas where J.P. "Serbia Forests" manages the established hunting ground "Kukavica", which is located at $1360 \mathrm{~m}$ above sea level.

The sex, genetic, age structure and number of populations of large autochthonous game species, which inhabit the forest areas of the municipality, are far below the possibilities of habitat potentials. The average game density is: roe deer 0.35 heads / 100 ha, partridge 10.44 heads / 100 ha, wild boar 0.20 heads / 100 ha, rabbit 9.28 heads / 100 ha and pheasant 6.57 heads / 100 ha.

\section{Methods and data}

The aim of the research is to assess whether the territory of the City of Leskovac and its surroundings have or have not the potential for the implementation of hunting tourism projects, including relevant factors that are part of the hunting area system. Also, this research will be focused on determining the capacity for the organization of hunting tourism that will affect: nature protection, conservation of biodiversity, economic benefits, as well as the sustainable development of rural areas.The paper applies a non-experimental model of scientific research, surveys, while the obtained results are processed by the statistical method of data processing.

The questionnaire shows that with 20 questions asked about the employment of hunting associations, owners of housing facilities that housed tourist hunters and directly tourists who were guests in hunting associations and used the services of hunting grounds, the research was conducted in the period from 2014 to 2019. They also used planning documentation from the archives of hunting associations to prepare the work.

On the territory of the town of Leskovac, there are 6 hunting grounds ("Dubocica", "Manojlovce", "Dobra glava", "Zec", "Porečje” and "Razgojna"), where the total area of the hunting area is 101.035 ha. The area of the hunting ground where hunting is allowed is 89.103 ha. In the hunting grounds themselves, eight shelters of $3.580 \mathrm{~m} 2$ for pheasants have been stationed, as well as 170 feeding grounds of $620 \mathrm{~m} 2$ for other feathered game. On an area of $839 \mathrm{~m} 2,65$ feeding grounds for furry game were built.

\section{Results and discussion}

The research was conducted in 6 hunting associations on the territory of the City of Leskovac in facilities that were in the function of tourist hunters. The questionnaires were relevant evidence of how many tourists stayed in hunting associations and how much income was generated by providing services to foreign and domestic tourists. The questionnaire also shows the result of investments in hunting associations in hunting production, hunting technical facil- 
ities and procurement of game. Here, it is very important to point out the key indicators that we will present in a table and graph.

Table 1. Number of tourist hunters who stayed in hunting associations (2017-2019)

\begin{tabular}{|c|c|c|c|c|c|c|c|c|c|c|c|c|}
\hline \multirow{2}{*}{$\begin{array}{l}\text { Hunting } \\
\text { Associatios }\end{array}$} & \multicolumn{2}{|c|}{2017} & \multicolumn{2}{|c|}{$\%$} & \multicolumn{2}{|c|}{2018} & \multicolumn{2}{|c|}{$\%$} & \multicolumn{2}{|c|}{2019} & \multicolumn{2}{|c|}{$\%$} \\
\hline & D & $\mathrm{F}$ & D & $F$ & D & $F$ & D & $\mathrm{F}$ & D & $F$ & D & $\mathrm{F}$ \\
\hline Dubočica & 17 & 35 & 12,6 & 25,9 & 18 & 46 & 11,7 & 29,9 & 16 & 52 & 8,6 & 27,9 \\
\hline Manojlovce & 3 & 23 & 2,2 & 17,0 & 1 & 34 & 0,6 & 22,2 & 2 & 39 & 1,1 & 20,9 \\
\hline Porečje & - & 14 & - & 10,4 & 1 & 15 & 0,6 & 9,7 & - & 13 & - & 6,9 \\
\hline Zec & - & 18 & - & 13,4 & - & 15 & - & 9,7 & 1 & 21 & 0,5 & 11,4 \\
\hline Dobra glava & - & 10 & - & 7,4 & - & 8 & - & 5,3 & - & 18 & - & 9,8 \\
\hline Razgojna & 1 & 14 & 0,8 & 10,4 & - & 16 & - & 10,4 & - & 24 & - & 12,9 \\
\hline Everything & 21 & 114 & 15,5 & 84,5 & 20 & 134 & 12,9 & 87,1 & 19 & 167 & 10,2 & 89,8 \\
\hline Total & \multicolumn{2}{|c|}{135} & & & \multicolumn{2}{|c|}{154} & & & \multicolumn{2}{|c|}{186} & & \\
\hline
\end{tabular}

Source: from the archives of hunting associations-Planning documentation, $D=$ domestic, $F=$ foreign

Observation of the total number of completed questionnaires-users of services, 475 (135 in 2017, 154 in 2018 and 186 in 2019) foreign tourist hunters were the dominant guests in relation to domestic tourist hunters, participating with $84.50 \%$ in relation to the total number tourist hunters in $2017,87.1 \%$ in 2018 and $89.8 \%$ in 2019.

The presented results also indicate a decreasing trend in the number of domestic tourist hunters from year to year. The reason for such a trend is the conditionally weak paying power of domestic tourists and the inability of domestic tourist hunters to respond to the exclusive offer in hunting grounds. Pešić and his associates came to the same knowledge (Pesić et al., 2017) and found that from the costs of mediation, transport, accommodation and food, through the payment of shooting tax, rental of weapons and equipment, to numerous other services provided to hunters during their stay in hunting ground and the hunting itself, received a great benefit that affects the result of a country's economy.

The concept of sustainable development is a relatively new concept aimed at overcoming the shortcomings of previous development models, primarily, neglecting environmental issues (Tešanović et al. 2015). Sustainable development strives to strike a balance between economic, environmental and social development. Hunters strive to make the most of wildlife growth while trying, at the same time, to fully maintain the foundation needed for reproduction. The principle of sustainability is even more clearly represented in forestry, and the mirror is in principle that no more trees are felled during the year, and what their nature can create, or even less (Riznić et al., 2019).

If we analyze the foreign exchange income from tourist hunters who stayed in Leskovac hunting associations, a trend of increasing income from year to year has been noticed. The revenues generated in this way contributed to the facilitated work of hunting associations. In this regard, Prentović (2005b) states that hunting tourism is the most profitable and most impulsive use of wildlife, as a natural resource. In that context, the same author added that hunting tourism is an export-oriented area of business and contributes to the realization of foreign exchange income of the hunting and tourism industry. 
Table 2. Income generated by the stay of tourist hunters in the period 2017-2019 (€).

\begin{tabular}{|l|c|c|c|c|c|c|}
\hline \multirow{2}{*}{$\begin{array}{l}\text { Hunting } \\
\text { Associatios }\end{array}$} & \multicolumn{2}{|c|}{$\mathbf{2 0 1 7}$} & \multicolumn{2}{c|}{$\mathbf{2 0 1 8}$} & \multicolumn{2}{c|}{2019} \\
\cline { 2 - 7 } & D & F & D & F & D & F \\
\hline Dubočica & 115 & 4.560 & 165 & 6.055 & 145 & 7.150 \\
\hline Manojlovce & 35 & 2.850 & 15 & 4.350 & 20 & 5.050 \\
\hline Porečje & - & 1.942 & 15 & 2.150 & - & 1.860 \\
\hline Zec & - & 2.105 & - & 2.150 & 15 & 2.650 \\
\hline Dobra glava & - & 1.150 & - & 940 & - & 2.240 \\
\hline Razgojna & 12 & 1.942 & - & 2.320 & - & 3.140 \\
\hline Everything $(€)$ & 162 & 14.549 & 195 & 17.965 & 180 & 22.090 \\
\hline Total $(€)$ & \multicolumn{2}{|c|}{17.711} & \multicolumn{2}{c|}{18.160} & \multicolumn{2}{c|}{22.270} \\
\hline
\end{tabular}

Source: from the archives of hunting associations-Planning documentation, $D=$ domestic, $F=$ foreign

Revenues generated by the stay of hunter-gatherers were used by hunting associations for the purchase of certain types of game as well as for the modernization of hunting technical facilities. The amount of realized income increased every year in 2018 by $2.3 \%$, and in 2019 , by $22.6 \%$. Financing of hunting associations is realized by collecting membership fees, which are paid annually. The realized income directly depends on the number of hunters, but those incomes are certainly insufficient for the improvement and modernization of the work of the hunting association. The funds generated by providing services to tourist hunters are earmarked for the construction of new hunting technical facilities and the purchase of game, mainly pheasant chickens. Due to the realization of significant financial resources, which, immediately after the realization, are returned to hunting with the aim of its further improvement, it is indisputable, as the competent authors point out, (Stojnić et al., 2015; Prentović, 2014; Marković et al., 2008) that hunting tourism is not only a significant form of business, but also a generator of further development of hunting, as a socially valuable economic activity.

At the same time, our income from hunting and hunting tourism is negligible and incomparably lower than the income from agriculture, but they are still very important for local communities. Revenues from hunting tourism could be multiplied if the problem with veterinary certificates and accompanying documentation for shot game originating from our hunting areas is solved.

Table 3. Number, constructed facilities and purchased pheasant chickens 2017-2019.

\begin{tabular}{|c|c|c|c|c|c|c|}
\hline \multirow{2}{*}{$\begin{array}{c}\text { Hunting } \\
\text { Associatios }\end{array}$} & \multicolumn{5}{|c|}{ Investments in hunting associations } \\
\cline { 2 - 7 } & $\mathrm{2}$ & $\mathbf{2 0 1 7}$ & \multicolumn{2}{c|}{$\mathbf{2 0 1 8}$} & \multicolumn{2}{c|}{2019} \\
\cline { 2 - 7 } & Pieces & birds & pieces & birds & pieces & birds \\
\hline Dubočica & 13 & 500 & 17 & 500 & 20 & 700 \\
\hline Manojlovce & 10 & 200 & 10 & 300 & 20 & 400 \\
\hline Porečje & 6 & 150 & 5 & 150 & 8 & 250 \\
\hline Zec & 5 & 200 & 7 & 200 & 7 & 300 \\
\hline Dobra glava & 5 & 150 & 6 & 100 & 8 & 150 \\
\hline Razgojna & 2 & 150 & 4 & 150 & 5 & 200 \\
\hline Total & 41 & 1.350 & 49 & 1.400 & 68 & 2.100 \\
\hline
\end{tabular}

Source: from the archives of hunting associations-Planning documentation, $O=$ objects, $W=$ wildlife 
Table 3 clearly shows that the professional services that manage hunting associations have placed special emphasis on the procurement of game because they have enriched their hunting grounds and met the needs of their members who are more interested in hunting feathered game, especially pheasants. While the rest of the feathered game, partridge, quail and pigeon hryvnia are left for the needs of foreign tourists. Investment and investment in the period from 2017-2019 in infrastructure was on an upward trajectory from $20.1 \%$ in 2018 to $38.8 \%$ in 2019 , while the funds allocated for the purchase of game were significantly higher $3.8 \%$ in 2018 , and $50 \%$ in 2019. In accordance with the financial income and possibilities, the professional services of hunting associations procure feathered game. The same attitude is shared by a group of authors (Marković et al., 2015) who clearly indicate that the care of game and domestic management of the hunting ground affects the occupancy of the economic capacity of the hunting ground and a more exclusive offer for tourist hunters. At the annual level, the number of purchased game was constantly increasing, by $4 \%$ in 2018 compared to 2017 , and $14.4 \%$ in 2019 . Also from the table we can notice that the number of hunting-technical facilities increases every year, and thus the conditions for stay and technical support to tourist hunters improve. Observing the number of constructed facilities, that percentage is much higher, even up to $200 \%$. In this way, not only does the number of game in the hunting ground increase, but local hunters, members of hunting associations, raise awareness and responsibility towards natural resources, and thus increase the hunting and tourist offer, says Ristić (2004).

If ecological awareness were applied and certain strategic measures were implemented, the preservation of large forest complexes would succeed, while together with the integrated management and establishment of a protected area, the value of the four most important ecosystem services in this area would increase. located on the border of Serbia, Bosnia and Herzegovina and Croatia: wood production, flood defense, pork production and biodiversity protection (Stankov et al., 2014).

\section{Conclusion}

Hunting and hunting tourism must be aimed at preserving habitats, preserving the environment and protecting wild species. Hunting tourism is a very important segment of the economic development of hunting associations and the entire territory in which hunting associations operate.

Hunting tourism in the preservation of biodiversity, rural development and protected areas can have a positive effect if viewed through financial gain, educational impact on domestic hunters, revitalization of forgotten hunting grounds, reduction of certain invasive species, animation of local population, but also negative through the extermination of many species, disturbing life cycles and disturbing the peace in the hunting ground as well as killing and capturing animals.

Hunting management also implies the principle of economic sustainability, whereby revenues must not be generated at the expense of sustainability. It is necessary to return the realized income to the hunting ground through investments in nature protection and breeding and protection of wildlife. The basic income of the hunting ground is realized through shooting, sale of trophies, game meat or sale of live game, as well as from the services provided in hunting. Part of the realized income is invested in the function of sustainable development of hunting areas, through the following elements: procurement of necessary equipment and food, undertaking preventive measures for game protection (sanitary measures, guard service, etc.), 
improvement of habitat conditions, installation of hunting facilities in the hunting ground, raising draws and shooting lines, winter feeding of game, etc.), formation of the parent flock, organizing tribunes and public debates on the protection of ecosystems, etc. Uncontrolled use of natural resources, wildlife and environmental pollution for current economic benefits have long-term negative consequences for all of humanity.

On the territory of the City of Leskovac, the interests of nature protection of agricultural land, forests and water, on the one hand, and the wildlife on which they live, on the other hand, are in conflict. Tourists have a significant contribution in generating income in hunting associations, foreign tourists are the dominant group in relation to domestic tourist hunters in terms of financial gain.

The number of hunters, both domestic and foreign, increases every year, and as a result of their presence, the financial profit, ie the economic effect of the mentioned resource, increases, and the distribution of profits is of key importance. Referral of income is a significant moment in preserving and providing the necessary resources for the procurement of game birds and the construction of hunting and technical facilities for game breeding and accommodation of foreign tourists.

The hunting potential of the area of the City of Leskovac has a tendency to grow and reach its maximum to achieve a greater economic effect, development of hunting associations, greater need for professional staff to be involved in this activity and improvement of infrastructure in hunting grounds.

\section{References}

Čomić, Đ. 1988. Spatial planning of tourism. Turizam 36(7-8), 183-187.

Garača, V., Vukosav, S., Stamenković, I., Bradić. M. 2019. Modelling of tourism region: Case of Novi Sad gravitational zone. Tourism 23(4), 178-189.

Lazić, L., Pavić, D., Stojanović, V., Tomić, P., Romelić, J., Pivac, T., Košić (Pavlica), K., Besermenji, S., Kicošev, S. and Đarmati, Z. 2008. Protected Areas and Ecotourism of Vojvodina. Prirodno-matematički fakultet, Novi Sad (in Serbian).

Law on Tourism (ZT) 2009. Official Gazette of RS, 36/o9.

Marković, V., Matejević, M., Kovačević, M. 2015. Establishment of hunting grounds and management in hunting. Prirodno-matematički fakultet, Novi Sad (in Serbian).

Marković,V., Davidović, N. (2008). Hunting tourism regionalization of Scandinavia, Contemporary tendencies in tourism, hospitality and gastronomy, Novi Sad: Faculty of Sciences, Department of Geography, Tourism and Hotel Management (in Serbian).

Marić, R. 2003. Hunting. Institute of Economic Sciences, Belgrade (in Serbian).

Pivac, T., Blešić, I., Besermenji, S., Gavrilović, D. 2020. Attitudes of local population on the importance of events nourishing culture and tradition of Croats in Vojvodina. Turizam 24(1), 46-56.

Prentović, R. 2005b. Hunting tourism. Prirodno-matematički fakultet, Novi Sad (in Serbian).

Prentović, R. 2008. Ethics of hunting tourism. Prirodno-matematički fakultet, Novi Sad (in Serbian).

Prentović, R. 2014. Hunting tourism activity. Prirodno-matematički fakultet, Novi Sad (in Serbian). 
Pešić, B., Stolić, N., Stančić, I., Lazić, M., Pešić, S. 2017. Organizational and economic conditions for improving biodiversity and hunting in the Jablanica district, in Ss. Cyril and Methodius, University Skopje, Book of abstracts 1(1) 18-19.

Pešić, B., Stolić, N., Zlatković, I., Zlatković, N., Pešić, S. 2019. Influence of ecological factors on the number of rabbits in the hunting ground "Kutlavica". Ecologica 26(93), 85-90 (in Serbian).

Riznić, D., Filipović, N., Milinčić, U. 2019. Development of sustainable rural tourism in the function of environmental protection from catastrophic phenomena. Ecologica 26(94) 146-152. (in Serbian).

Ristić, Z. 2004. Feathered game as part of the hunting and tourist offer of Vojvodina Doctoral dissertation, Faculty of sciences, Novi Sad. (in Serbian).

Stolić, N., Pešić, B., Zlatković, N., Milošević, B., Spasić, Z., Ilić, Z. 2019. Controlled breeding and nutritional criteria as a conservation programme of the grey partridge (Perdix perdix L), Publicher-Bulgarian National Multidisciplinary Scientific Network of the Professional Society for Reserch work 1, 232-237.

Stojnić, N., Panjković, B., Sabadoš, K., Kicošev, V., Kiš, A., Galamboš, L., Delić, J., Dobretić, V., Milenić, B., Perić, R., Stojšić, V., Pil, N., Stanišić, J., Plemić, Z., Predojević, J., Bošnjak, T., Mihajlović, N., Fojkar, O., Došenović, B., Marinković, L., Krnčević, G., Borčić, S., Novaković, S., Rilak, S., Dragaš, K., Pivaš, B. 2015. Report on the state of nature in the Autonomous Province of Vojvodina for the period 2010-2014, Provincial Institute for Nature Protection, 252, Novi Sad (in Serbian).

Stankov, B., Gačić, D., Stamenkovi, S. 2014. Remediation of the consequences of the catastrophic flood in 2014 in the hunting ground "Bosutske šume" (Vojvodina), Ecologica 26(96) 493498 (in Serbian).

Tešanović, D., Vuksanović, N., Kalenjuk, B., Portić, M. 2015. Tourist ships on the Danube as an opportunity for export of meat and meat products, Economics of Agriculture 62(2), 527542.

Trišić, I. 2020. Using Indicators to Assess Sustainable Tourism Development - The Case of Protected Natural Areas of Vojvodina (Northern Serbia), Turizam 24(4), 178-193.

Whitelaw, P.A., King-Brian E.M., Tolkach, D. 2014. Protected Areas, Conservation and Tourism - Financing the Sustainable Dream. Journal of Sustainable Tourism 22(4), 584-603.

Internet 1: http://www.lss.rs/ (01.07.2020) 